\title{
PROGRAM LANSIA \\ WILAYAH PUSKESMAS SINGAPARNA KABUPATEN TASIKMALAYA TAHUN 2017
}

\author{
OLEH: \\ Santi Susanti, SST, M.Kes, Hariyani S, S.KM,M.KM, \\ Fenty Agustini, S.ST, M.Kes, Tupriliany Danefi, S.ST, M.Kes \\ Wuri Ratna Hidayani, S.KM, M.Sc
}

\section{A. DASAR PEMIKIRAN}

Persoalan

reproduksi bukan hanya

persoalan kesehatan reproduksi

perempuan secara sempit dengan mengaitkannya pada masalah seputar perempuan usia subur, kehamilan dan persalinan. Secara lebih spesifik, berbagai masalah dalam kesehatan reproduksi mulai dari perawatan kehamilan, pertolongan pada persalinan, infertilitas, penggunaan kontrasepsi, kehamilan tidak diinginkan dan aborsi, penyakit menular seksual dan HIV/AIDS, pelecehan dan kekerasan pada perempuan, perkosaan, layanan dan informasi pada remaja, serta menopause pada perempuan dewasa, merupakan bagian dari upaya memberikan pendidikan kepada masyarakat tentang pentingnya kesadaran kesehatan reproduksi bagi individu, khususnya bagi perempuan. Dengan demikian, dapat dikatakan bahwa seluruh tingkatan hidup perempuan merupakan fokus persoalan kesehatan reproduksi itu sendiri.

Menurut Manuaba sampai akhir abad 21, diperkirakan antara $8 \%-10 \%$ penduduk Indonesia adalah lansia dan lansia perempuan akan lebih banyak dibandingkan dengan laki-laki. Badan Kesehatan Dunia atau WHO (World Health Organization) menyebutkan bahwa ledakan menopause pada tahun-tahun mendatang sulit sekali dibendung dan diperkirakan di tahun 2030 nanti ada sekitar 1,2 miliar perempuan yang berusia diatas 50 tahun. Sebagian besar dari mereka (sekitar 80\%) tinggal di negara berkembang dan setiap tahunnya populasi perempuan menopause meningkat sekitar tiga persen. 3 Artinya kesehatan perempuan khususnya patut mendapatkan perhatian, sehingga akan meningkatkan angka harapan hidup dan tercapainya kebahagiaan serta kesejahteraan secara psikologis.

Dalam rangkaian disnatalis STIKes Respati Tasikmalaya ke-15 dilaksanakan program pengabdian masyarakat pemeriksaan status kesehatan lanjut usia di wilayah kerja puskesmas Singaparna Kabupaten Tasikmalaya tahun 2017.

\section{B. TUJUAN}

Program ini bertujuan untuk meningkatkan partisipasi masyarakat dalam pemantauan status kesehatan lanjut usia. Diharapkan dari kegiatan ini dapat diidentifikasi status kesehatan lansia dan dapat menigkatkan pengetahuan para lansia tentang status gizi yang baik di usia senja 


\section{BENTUK KEGIATAN}

Program pengadian masyarakat pemeriksaan status kesehatan lansia adalah sebagai berikut :

\begin{tabular}{|c|c|c|c|c|}
\hline No & $\begin{array}{l}\text { Nama } \\
\text { Kegiatan }\end{array}$ & Tujuan & Petugas & $\begin{array}{l}\text { Penanggung } \\
\text { Jawab }\end{array}$ \\
\hline 1 & $\begin{array}{l}\text { Gerakan } \\
\text { senam lansia }\end{array}$ & $\begin{array}{l}\text { Meningkatkan } \\
\text { kesadaran } \\
\text { masyarakat } \\
\text { lansia untuk } \\
\text { berolahraga }\end{array}$ & 2 orang kader & $\begin{array}{l}\text { Santi Susanti, } \\
\text { S.ST, M.Kes }\end{array}$ \\
\hline 2 & $\begin{array}{l}\text { Pemeriksaan } \\
\text { TB dan BB }\end{array}$ & $\begin{array}{l}\text { Pendekteksian } \\
\text { dini status gizi } \\
\text { pada lansia }\end{array}$ & $\begin{array}{ll}2 & \text { mahasiswa } \\
\text { kebidanan } & \end{array}$ & \multirow[t]{3}{*}{$\begin{array}{l}\text { Petugas } \\
\text { Puskesmas }\end{array}$} \\
\hline 3 & $\begin{array}{l}\text { Pemeriksaan } \\
\text { tekanan darah }\end{array}$ & $\begin{array}{l}\text { Pendekteksian } \\
\text { dini hipertensi } \\
\text { pada lansia }\end{array}$ & Petugas Puskesmas & \\
\hline 4 & $\begin{array}{l}\text { Pemeriksaan } \\
\text { lingkar Perut }\end{array}$ & $\begin{array}{l}\text { Pendeteksian } \\
\text { status gizi } \\
\text { lansia }\end{array}$ & 1 orang mahasiswa & \\
\hline 4 & $\begin{array}{l}\text { Pemeriksaan } \\
\text { gula darah }\end{array}$ & \begin{tabular}{lr}
\multicolumn{2}{l}{ Pendekteksian } \\
dini & diabetes \\
militus & pada \\
lansia &
\end{tabular} & \multirow[t]{2}{*}{$\begin{array}{ll}\text { Laboran } & \text { Puskesmas } \\
\text { dan } 3 & \text { mahasiswa } \\
\text { kebidanan } & \end{array}$} & \multirow[t]{2}{*}{$\begin{array}{l}\text { Laboran } \\
\text { Puskesmas }\end{array}$} \\
\hline 4 & $\begin{array}{l}\text { Pemeriksaan } \\
\text { kolesterol } \\
\text { darah }\end{array}$ & $\begin{array}{l}\text { Pendeteksian } \\
\text { dini kolesterol } \\
\text { pada lansia }\end{array}$ & & \\
\hline 5 & $\begin{array}{l}\text { Penyuluhan } \\
\text { Status Gizi } \\
\text { Pada Lansia }\end{array}$ & $\begin{array}{l}\text { Meningkatkan } \\
\text { pengetahuan } \\
\text { lansia tentang } \\
\text { kebutuhan } \\
\text { nutrisi di usia } \\
\text { lanjut }\end{array}$ & $\begin{array}{ll}\text { - } & \text { Haryani } \\
\text { Sulistyoningsih, } \\
\text { S.KM, M.KM }\end{array}$ & $\begin{array}{l}\text { Haryani } \\
\text { Sulistyoningsih, } \\
\text { S.KM, M.KM }\end{array}$ \\
\hline 6 & Registrasi & $\begin{array}{l}\text { Mengetahui } \\
\text { status kesehatan } \\
\text { rproduksi lansia }\end{array}$ & $\begin{array}{ll}\text { - } & \text { Fenty Agustini, } \\
& \text { S.ST, M.Kes } \\
\text { - } & \text { Tupriliany Danefi, } \\
& \text { S.ST, M.Kes } \\
\text { - } & \text { Wuri Ratna } \\
& \text { Hidayani, S.KM, } \\
\text { M.Sc } \\
\text { - } & 1 \text { orang mahasiswa }\end{array}$ & $\begin{array}{l}\text { Wuri Ratna } \\
\text { Hidayani, } \\
\text { S.KM, M.Sc }\end{array}$ \\
\hline
\end{tabular}


Pemeriksaan status kesehatan lansia berjalan dengan lancar. Petugas puskesmas memberikan dukungan untuk STIKes membina program posbindu. Para lansia bersemangat dalam mengikuti semua program.

Adapaun saran untuk perbaikan program sebaiknya pendeteksian dini melalui pemeriksaan laboratorium dapat dilaksanakan untuk seluruh peserta, dan pembinaan posbindu dapat dikembangkan sebagai program pengabdian masyarakat yang berkelanjutan.

\section{SASARAN}

Peserta program adalah peserta aktif posbindu di wilayah kerja Puskesmas Singaparna dengan jumlah 74 orang.

\section{E. WAKTU DAN TEMPAT}

Pelaksanaan program dilaksanakan pada hari Kamis, 30 November 2017 bertempat di STIKes Respati Tasikmalaya.

\section{F. HASIL KEGIATAN}

Hasil kegiatan terdiri dari :

1. Pemeriksaan kesehatan lansia

Pemeriksaan yang meliputi : pemeriksaan status gizi, pemeriksaan kolesterol, pemeriksaan gula darah dan asam urat.

2. Senam lansia

Senam lansia diikuti oleh 74 orang lansia dengan instruktur senam dari kader posyandu.

3. Penyuluhan kesehatan reproduksi dan nutrisi bagi lansia

\section{G. DOKUMENTASI}

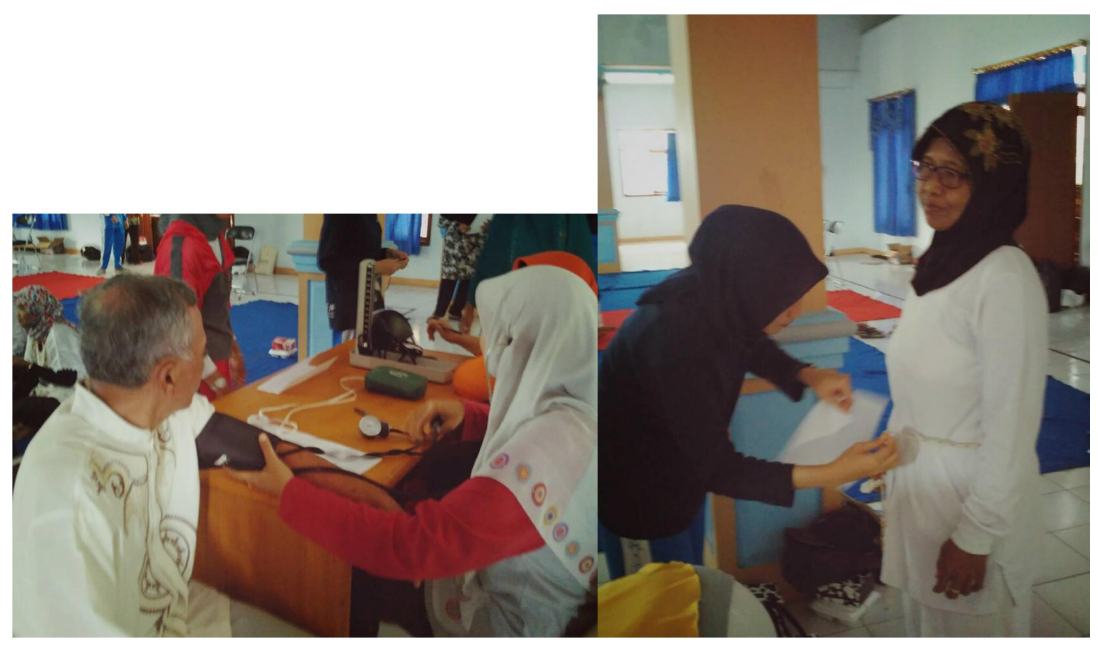




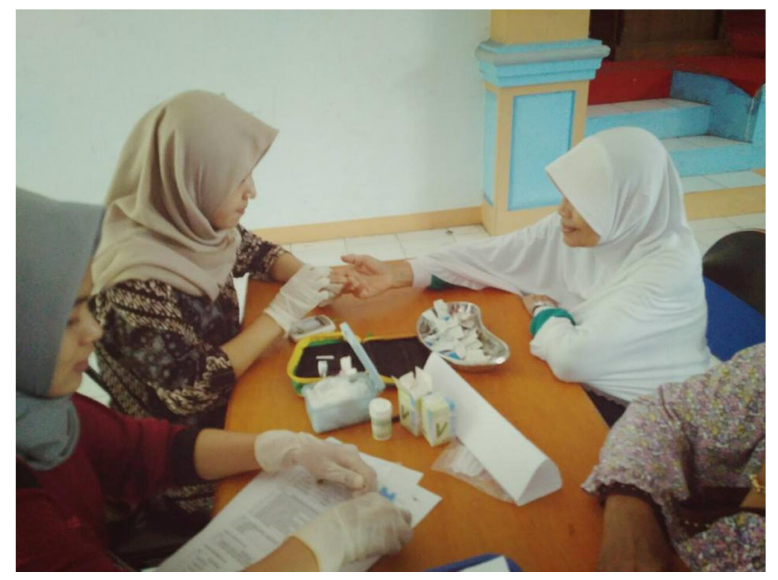

Gambar 1 Pemeriksaan lansia
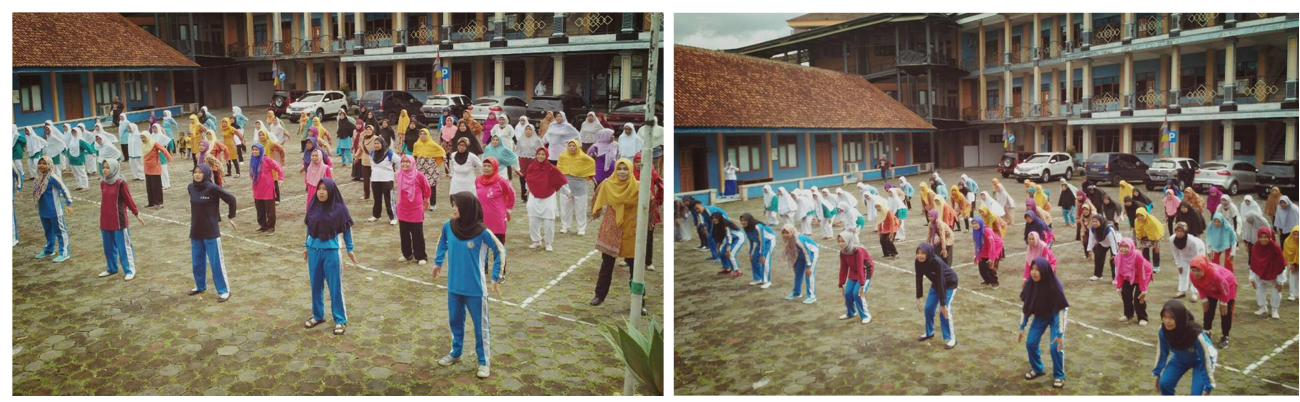

Gambar 2 Senam lansia

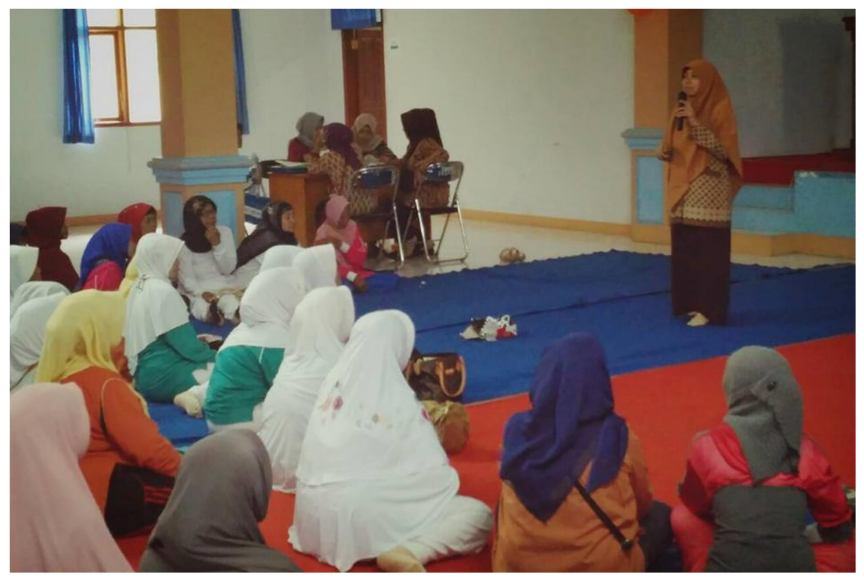

Gambar 3 Penyuluhan Gizi dan kespro lansia 